\title{
A Review on Genetic Engineering of Microalgae with Respect to Genomes, Selectable Marker Genes, Promoters and Reporter Genes
}

\author{
Jayant Pralhad Rathod ${ }^{1 *}$, Rajendra M. Gade ${ }^{1}$, Darasing R. Rathod ${ }^{2}$ and \\ Mahendra Dudhare ${ }^{1}$ \\ ${ }^{1}$ Vasantrao Naik College of Agricultural Biotechnology, Dr. Panjabrao Deshmukh Krishi \\ Vidyapeeth, Waghapur Road, Yavatmal-445001, Maharashtra, India \\ ${ }^{2}$ Dr. Panjabrao Deshmukh Krishi Vidyapeeth, P.O. Krishi Nagar, Akola-444104, \\ Maharashtra, India \\ *Corresponding author
}

\begin{tabular}{|c|c|}
\hline & A B S T R A C T \\
\hline & of the \\
\hline Keywords & potential of this microbe in the field of agriculture, therapeutic recombinant \\
\hline $\begin{array}{l}\text { Microalgae, Genome, } \\
\text { Selectable marker, } \\
\text { Promoter, Reporter. }\end{array}$ & $\begin{array}{l}\text { proteins, environment, bioenergy and so on. To work on basic understanding and } \\
\text { production of different metabolites from microalgae, information with respect to } \\
\text { gene sequences available, promoter, genome, selectable marker, and reporter is }\end{array}$ \\
\hline Article Info & $\begin{array}{l}\text { required. Nuclear, chloroplastic and other organeller genome information is } \\
\text { available online which helps in better understanding of this microalgae }\end{array}$ \\
\hline $\begin{array}{l}\text { Accepted: } \\
\text { 23 October } 2017 \\
\text { Available Online: } \\
10 \text { December } 2017\end{array}$ & $\begin{array}{l}\text { Information with respect to various promoters, selectable markers and reporter } \\
\text { genes helps to design different strategies for genetic manipulation of microalgae } \\
\text { for production of a variety of value added compounds and fundamental studies of } \\
\text { this very promising microorganism. }\end{array}$ \\
\hline
\end{tabular}

\section{Introduction}

Genetic engineering of algae is an intricate and fast-growing field in biofuel research used for commercial production of fatty acids, pigments, vitamins, proteins, food and feed additives, polysaccharides, cosmetics and biomass (Hallmann 2007). The progress in algal transgenic promises to broaden the existing repertoire of products that have relevance either for medicinal or industrial valuable proteins and/or metabolites by molecular farming. Production of recombinant vaccines, antibodies, biohydrogen, insecticidal proteins and so on has been demonstrated in transgenic algae by few authors and the field is still growing (Wang et al., 2012; Gimpel et al., 2015; Rathod et al., 2016). Genetic modifications facilitate to enhance desired physiological chances of algal strains along with few optimization measures in production systems will further improve the prospective of this promising technology in the near future. Normally, single species may not show all the desired traits of interest for commercial production of certain metabolites. Therefore, cautious selection of a suitable target organism and 
source of gene should be prioritized at the beginning of every algal transformation experiment (Vira et al., 2016, Hallmann 2007). Several optimization parameters have to be defined such as short life cycle of algae, inexpensive media and high growth rate at different conditions has to be standardized. With respect to these specific characteristics, transformation method needs to be developed or be available for selection of transformed alga (Rathod et al., 2013).

It is also useful to employ an alga in which collections of mutants exist or can be easily generated; but few have their own limitations (Hallmann 2007). Moreover, knowledge on ecological, physiological, molecular or biochemical characteristics of the target species is essential. However, existence of annotated sequence information of algal strains is required for algal transgenic but this is still in its infancy (Kim et al., 2015). The current review focuses on available genome, promoter, selection marker and reporter information in microalgae for designing different molecular biology experiments for fast track development of this emerging field.

\section{Algal genomes}

Complete knowledge about the genome sequence is one of the essential features required for genetic manipulations in algae. The genome sequence offers advantages in terms of ease in genetic transformation studies with respect to homology of genes from different sources and site of integration within the genome. Till date, complete genome sequences of more than 20 algal species are available (Gan et al., 2016) the details of which are as shown in Table 1 . The genome data is increasing exponentially for algae which are evident from 60 new algal genome projects under progress (Bhattacharya et al., 2015).
Along with nuclear, chloroplast and mitochondrial genomes as discussed, expressed sequence tags (ESTs) also provide the most important sequence information required for molecular genetics and metabolic engineering of microalgae (Gan et al., 2016). ESTs are short, unedited, single pass sequence reads derived from randomly selected complementary DNA (cDNA) libraries. ESTs accelerate gene discovery, complement genome annotation, aid in gene structure identification, establish the viability of alternative transcripts, and facilitate proteome analysis (Hallman, 2007). Recently, there have been advances in sequenced expressed sequence tags (ESTs) among algae, namely, Chlamydomonas reinhardtii, Ostreococcus tauri and Acetabularia acetabulum, the red algae Porphyra yezoensis, Gracilaria gracilis, Galdieria sulphuraria, and so on (Tirichine and Bowler, 2011; Bhattacharya et al., 2015). EST data of algal species are available publicly at National Center for Biotechnology Information (NCBI) (http://www.ncbi.nlm. nih.gov/projects/dbEST/) and the Taxonomically Broad EST Database (TBestDB, http://amoebidia.bcm.umontreal. ca/pepdb/searches/welcome.php).

Because of much smaller size of plastid genomes, sequencing of chloroplast and mitochondrial genomes has been performed for more algal species (more than 20) than the genome for EST sequencing projects (Hallman, 2007; Melton et al., 2015). This genome information proves very helpful during chloroplastic or mitochondrial transformation or targeting different proteins to these plastids. The genome sequences for chloroplast and mitochondria are available at the NCBI organelle database (http://www.ncbi.nlm.nih.gov/genomes/ORG ANELLES/ organelles.html) and the Organelle Genome Database (GOBASE, http: //www.bch. umontreal.ca/gobase/gobase. 
html). Organelle genome mega sequencing program have been used to generate many organelle sequences (OGMP, http: //www.bch.umontreal.ca /ogmp/) (Hallman, 2007). All the above information will help to answer the phylogenetic questions and to gain a better understanding of the organellar genomic composition (Melton et al., 2015).

\section{Selectable marker genes}

Selectable marker genes form an integral part of the transformation process as they assist in selection of transgenic algae. These marker genes are often antibiotic resistance genes and/or auxotrophic mutants with mutations in the corresponding endogenous gene(s). The antibiotic resistant gene is either a dominant or a recessive marker and it confers a new trait to any transformed algal strain. Array of dominant selectable markers are available for algae from a variety of sources which confer antibiotic or herbicide resistance. Table 2 lists markers and their functions in various algal species. Most of the genetic manipulation studies have been carried out in model microalgae $C$. reinhardtii and the maximum numbers of selectable marker genes have been established for this alga. Few examples are discussed in here such as the aminoglycoside phosphortransferase (aph7) gene from Streptomyces hygroscopicus confers resistance against the herbicide hygromycin B (Berthold et al., 2002). The mutated acetolactate synthase (ALS) gene from $C$. reinhardtii provides tolerance to sulfonylurea herbicides (Kovar et al., 2002). The aminoglycoside phosphotransferase aphVIII (aphH) gene from Streptomyces rimosus provides resistance against paromomycin (Sizova et al., 2001). The mutated protoporphyrinogen oxidase (PPX1) gene from $C$. reinhardtii confers resistance towards N-phenyl heterocyclic herbicide S23142 (Randolph-Anderson et al., 1998). The synthetic aminoglycoside adenyltransferase $\begin{array}{llll}(\operatorname{aad} A) & \text { gene } & \text { from } & \mathrm{R} 100.1\end{array}$ plasmid/bacteriophage T4/ confers resistance to spectinomycin and streptomycin (Cerutti et al., 1997). Ble gene from Streptoalloteichus hindustanus confers resistance towards zeomycin and phleomycin (Stevens et al., 1996). The mutated ribosomal protein S14 (CRY1) gene of $C$. reinhardtii provides resistance to emetine and cryptopleurine (Nelson et al., 1994).

In $H$. pluvialis, the modified gene, phytoene desaturase (pdsMod4.1), confers resistance to the bleaching herbicide norflurazon by accelerated astaxanthin biosynthesis (Steinbrenner and Sandmann, 2006). In $C$. vulgaris, similar to $C$. reinhardtii, the Streptomyces hygroscopicus aminoglycoside phosphotransferase gene provided resistance against hygromycin (Chow and Tung, 1999) with CaMV35S promoter which is usually used in transgenic higher plants. In $L$. japonica, hygromycin resistance was acquired by a simian virus 40 (SV40) promoterhygromycin phosphotransferase chimeric gene (Qin et al., 1999). The SV40 virus, found in humans and monkeys, is a quite surprising promoter that works in brown alga L. japonica (Qin et al., 1999).

In diatom $P$. tricornutum, various genes produce antibiotic resistance against different antibiotics. The neomycin phosphotransferase II (nptII) gene provides resistance against aminoglycoside antibiotic G418 (Zaslavskaia et al., 2000) whereas the nat and sat-1 genes confer resistance against antibiotic nourseothricin (Zaslavskaia et al., 2000). The Strepto-alloteichus hindustanus ble gene was shown to produce resistance against zeomycin (Apt et al., 1996; Falciatore et al., 1999) and the expressed chloramphenicol acetyltransferase gene (CAT) confers resistance against the antibiotic chloramphenicol (Apt et al., 1996). 
Table.1 List of completed genome sequences of algae

\begin{tabular}{|c|c|c|c|}
\hline $\begin{array}{l}\text { Type of } \\
\text { genome }\end{array}$ & Algae species & GenBank Number & Reference \\
\hline \multirow{13}{*}{ Nuclear } & $\begin{array}{l}\text { Chlamydomonas } \\
\text { reinhardtii }\end{array}$ & ABCN00000000 & Merchant et al., 2007 \\
\hline & Chlorella variabilis & ADIC01000000 & Blanc et al., 2010 \\
\hline & Micromonas pusilla & ACCP00000000 & Worden et al., 2009 \\
\hline & $\begin{array}{l}\text { Ostreococcus } \\
\text { lucimarinus }\end{array}$ & СР000581-СР000601 & Palenik et al., 2007 \\
\hline & Ostreococcus tauri & CR954201-CR954220 & Derelle et al., 2006 \\
\hline & $\begin{array}{l}\text { Volvox carterif. } \\
\text { nagariensis }\end{array}$ & ACJH00000000 & Prochnik et al., 2010 \\
\hline & $\begin{array}{c}\text { Nannochloropsis } \\
\text { gaditana }\end{array}$ & AGNI00000000.1 & $\begin{array}{l}\text { Radakovits } \text { et al., } \\
2012\end{array}$ \\
\hline & $\begin{array}{c}\text { Nannochloropsis } \\
\text { oceanic }\end{array}$ & AFGK00000000.1 & Pan et al., 2011 \\
\hline & $\begin{array}{c}\text { Thalassiosira } \\
\text { oceanic }\end{array}$ & GU323224.1 & Lommer et al., 2012 \\
\hline & $\begin{array}{c}\text { Cyanidioschyzon } \\
\text { merolae }\end{array}$ & AP006483(DDBJ) & Matsuzaki et al., 2004 \\
\hline & $\begin{array}{c}\text { Galdieria } \\
\text { sulphuraria }\end{array}$ & ADNM00000000.2 & $\begin{array}{l}\text { Muravenko et al., } \\
\text { 2001; Barbier et al., } \\
2005\end{array}$ \\
\hline & Emiliania huxleyi & AHAL0000000 & Read et al., 2013 \\
\hline & $\begin{array}{l}\text { Parachlorella } \\
\text { kessleri }\end{array}$ & BBXU00000000.1 & Ota et al., 2016 \\
\hline \multirow{7}{*}{ Chloroplast } & $\begin{array}{l}\text { Phaeodactylum } \\
\text { tricornutum }\end{array}$ & EF067920 & $\begin{array}{l}\text { Oudot-Le Secq et al., } \\
2007\end{array}$ \\
\hline & C. reinhardtii & BK000554 & Maul et al., 2002 \\
\hline & Chlorella vulgaris & AB001684 & Wakasugi et al., 1997 \\
\hline & P. kessleri & FJ968741 & Turmel et al., 2009 \\
\hline & $\begin{array}{l}\text { Cryptomonas } \\
\text { paramecium }\end{array}$ & GQ358203 & Donaher et al., 2009 \\
\hline & Rhodomonas salina & EF508371 & Khan et al., 2007 \\
\hline & E. huxleyi & AY741371 & Puerta et al., 2005 \\
\hline \multirow[b]{2}{*}{ Mitochondrion } & C. reinhardtii & U03843 & Maul et al., 2002 \\
\hline & Dunaliella salina & $\begin{array}{c}\text { CCAP19/18 - } \\
\text { GQ250045 }\end{array}$ & Smith et al., 2010 \\
\hline
\end{tabular}


Table.2 List of selectable markers in algae

\begin{tabular}{|c|c|c|c|}
\hline Algal culture & $\begin{array}{l}\text { Gene for antibiotic } \\
\text { resistance }\end{array}$ & $\begin{array}{c}\text { Resistance against } \\
\text { antibiotic/herbicide }\end{array}$ & Reference/s \\
\hline \multirow[t]{7}{*}{ C. reinhardtii } & $\begin{array}{c}\text { Aminoglycoside } \\
\text { phosphortransferase }\end{array}$ & Hygromycin B & Berthold et al., 2002 \\
\hline & Acetolactate synthase & Sulfonylurea & Kovar et al., 2002 \\
\hline & $\begin{array}{c}\text { Aminoglycoside } \\
\text { phosphotransferase }\end{array}$ & Paromomycin & Sizova et al., 2001 \\
\hline & $\begin{array}{c}\text { Protoporphyrinogen } \\
\text { oxidase }\end{array}$ & $\begin{array}{c}\text { N-phenyl } \\
\text { heterocyclic } \\
\text { herbicide S-23142 }\end{array}$ & $\begin{array}{l}\text { Randolph-Anderson } \\
\text { et al., } 1998\end{array}$ \\
\hline & $\begin{array}{l}\text { Aminoglycoside } \\
\text { adenyltransferase }\end{array}$ & $\begin{array}{l}\text { Spectinomycin and } \\
\text { Streptomycin }\end{array}$ & Cerutti et al., 1997 \\
\hline & $\begin{array}{l}\text { Strepto-alloteichus } \\
\text { hindustanus (ble) }\end{array}$ & $\begin{array}{l}\text { Zeomycin and } \\
\text { Phleomycin }\end{array}$ & Stevens et al., 1996 \\
\hline & $\begin{array}{l}\text { Mutated ribosomal } \\
\text { protein } \mathrm{S14}\end{array}$ & $\begin{array}{l}\text { Emetine and } \\
\text { Cryptopleurine }\end{array}$ & Nelson et al., 1994 \\
\hline $\begin{array}{c}\text { Haematococcus } \\
\text { pluvialis }\end{array}$ & Phytoene desaturase & Norflurazon & $\begin{array}{l}\text { Steinbrenner and } \\
\text { Sandmann, } 2006\end{array}$ \\
\hline C. vulgaris & $\begin{array}{c}\text { Aminoglycoside } \\
\text { phosphotransferase }\end{array}$ & Hygromycin & $\begin{array}{l}\text { Chow and Tung, } \\
1999\end{array}$ \\
\hline $\begin{array}{c}\text { Dunaliella } \\
\text { bardawil }\end{array}$ & $\begin{array}{c}\text { Hygromycin } \\
\text { phosphotransferase }\end{array}$ & Hygromycin & Anila et al., 2011 \\
\hline Schizochytrium & $\begin{array}{c}\text { neomycin } \\
\text { phosphotransferase II }\end{array}$ & G418 & Cheng et al., 2012 \\
\hline $\begin{array}{l}\text { Laminaria } \\
\text { japonica }\end{array}$ & $\begin{array}{c}\text { Hygromycin } \\
\text { phosphotransferase }\end{array}$ & Hygromycin & Qin et al., 1999 \\
\hline \multirow[t]{4}{*}{$\begin{array}{c}\text { Phaeodactylum } \\
\text { tricornutum }\end{array}$} & $\begin{array}{c}\text { Neomycin } \\
\text { phosphotransferase II }\end{array}$ & G418 & $\begin{array}{l}\text { Zaslavskaia et al., } \\
2000\end{array}$ \\
\hline & Nat and Sat-1 & Nourseothricin & $\begin{array}{l}\text { Zaslavskaia et al., } \\
2000\end{array}$ \\
\hline & $\begin{array}{l}\text { Streptoalloteichus } \\
\text { hindustanus (ble) }\end{array}$ & Zeomycin & $\begin{array}{l}\text { Apt et al., 1996; } \\
\text { Falciatore et al., } 1999\end{array}$ \\
\hline & $\begin{array}{l}\text { Chloramphenicol } \\
\text { acetyltransferase }\end{array}$ & Chloramphenicol & Apt et al., 1996 \\
\hline $\begin{array}{l}\text { Cylindrotheca } \\
\text { fusiformis }\end{array}$ & $\begin{array}{l}\text { Streptoalloteichus } \\
\text { hindustanus (ble) }\end{array}$ & Zeomycin & Fischer et al., 1999 \\
\hline $\begin{array}{l}\text { Navicula } \\
\text { saprophila }\end{array}$ & $\begin{array}{c}\text { Neomycin } \\
\text { phosphotransferase II }\end{array}$ & G418 & Dunahay et al., 1995 \\
\hline $\begin{array}{l}\text { Cyclotella } \\
\text { cryptica }\end{array}$ & $\begin{array}{c}\text { Neomycin } \\
\text { phosphotransferase II }\end{array}$ & G418 & Dunahay et al., 1995 \\
\hline $\begin{array}{l}\text { Symbiodinium } \\
\text { microadriaticum }\end{array}$ & $\begin{array}{c}\text { Hygromycin } \\
\text { phosphotransferase }\end{array}$ & Hygromycin & $\begin{array}{l}\text { Te Lohuis and } \\
\text { Miller, } 1998\end{array}$ \\
\hline Amphidinium sp. & $\begin{array}{c}\text { Neomycin } \\
\text { phosphotransferase II }\end{array}$ & G418 & $\begin{array}{l}\text { Te Lohuis and } \\
\text { Miller, } 1998\end{array}$ \\
\hline
\end{tabular}


In another diatom, C. fusiformis, expression of the Streptoalloteichus hindustanus ble gene confers resistance to zeomycin under the control of endogenous calcium-binding glycoprotein $\alpha$-frustulin frua3 promoter (Fischer et al., 1999). Likewise, in the diatoms $N$. saprophila and $C$. cryptic, the nptII gene confers resistance to the antibiotic G418 (Dunahay et al., 1995). The transformation of $S$. microadriaticum and dinoflagellates Amphidinium sp. was shown by using the nptII gene, or the hygromycin $B$ phosphotransferase gene (hpt) (Te Lohuis and Miller, 1998). Thus, marker genes play essential role based on specific species used for transformation studies. Besides these dominant selection markers, there is another category which is based on recessive markers in algae. The advantage of recessive markers is that a complete endogenous gene with its own promoter is applicable, though they require auxotrophic mutants with mutations in the corresponding endogenous gene.

The expression and function of recessive selectable markers is quite certain in the respective organism. For example, in $C$. reinhardtii, Dunaliella viridis, Chlorella sorokiniana, Volvox carteri, and Ulva lactuca, a very common recessive marker is the nitrate reductase (nit) gene. It is used for functional complementation of nitrate reductase defective mutants (Kindle et al., 1989; Sun et al., 2006; Dawson et al., 1997; Schiedlmeier et al., 1994; Huang et al., 1996). Similarly, argininosuccinate lyase (ASL) gene was shown to complement mutations in argininosuccinate lyase defective $C$. reinhardtii mutants by selection on argininefree medium (Debuchy et al., 1989). Studies in Cyanidioschyzon merolae show that the wild-type UMP synthase gene complements mutated $C$. merolae UMP synthase gene for uracil prototrophy (Minoda et al., 2004). Thus, these wide ranges of selectable markers can act as a basis for selection of transformants while optimizing transformation of a novel algal strain.

\section{Promoter and reporter genes}

Promoters could drive the expression of the antibiotic resistance genes i.e. foreign or indigenous genes as well as the reporter genes. Selection of promoter is another vital step for gene transcription process. In most of the cases, selectable marker genes are not able to express by using their own indigenous promoter, especially if the gene source is from a different organism (Hallmann, 2007). However, to address this problem, usually strong, constitutive and/or inducible promoters are used. For higher expression, endogenous promoters are also used as selectable markers or other chimeric gene constructs (Hallmann, 2007).

In algae, various promoters derived from different organisms have been used. For example, CaMV 35S and SV40 promoters from viruses have been used to express target genes in algae (Benfey et al., 1990; Wang et al., 2010). However, the algal genes which usually expresses highly, provide the most effective promoters for gene expression. For example, Chlamydomonas heat shock protein 70A gene hsp70A (Schroda et al., 2000) and $5^{\prime}$ untranslated region of the $C$. reinhardtii $\mathrm{RuBisCO}$ small subunit ( $r b c S 2)$ gene (Stevens et al., 1996), are widely used promoters in Chlamydomonas transformation. Reports demonstrate the use of promoters of duplicated carbonicanhydrase1 (DCA1) in Dunaliella sp. (Li et al., 2010; Lu et al., 2011), fucoxanthin-chlorophyll a/c binding protein $(f c p)$ gene in marine diatom (Apt et al., 1996; Miyagawa-Yamaguchi et al., 2011), actin1 (PyAct1) gene in Porphyra yezoensis (Takahashi et al., 2010), and violaxanthin/ chlorophyll a-binding protein (VCP) genes in Nannochloropsis sp. (Kilian et al., 2011). Perhaps, for the confirmation of 
transformation event and its visual detection and identification of expressed reporter protein, different genes are extensively demonstrated in algae. Reporter genes usually code for fluorescent protein, enzymes that convert a colorless substrate into a colored product, or result in light emission. For example, endogenous arylsulfatase (ARS) gene is a valuable reporter gene which converts chromogenic substrates like 5bromo-4-chloro-3-indolyl sulphate $\left(\mathrm{X}-\mathrm{SO}_{4}\right)$ or p-nitrophenyl sulfate into color compound allowing analysis, both at subcellular localization as well as spectrophotometric quantification of arylsulfatase activity (Davies et al., 1992; Hallmann and Sumper, 1994).

A codon-optimized green fluorescent protein (GFP) gene which does not require any additives for GFP detection, can be visualize using fluorescent microscope (Fuhrmann et al., 1999; Ender et al., 2002). Examples of other reporter genes are the codon-optimized Renilla reniformis luciferase (crluc) gene in C. reinhardtii, or the Chlorella kessleri hexose/H+ symporter (HUP1) gene in Volvox carteri (Fuhrmann et al., 2004; Hallmann, 2007).

Escherichia coli $\beta$-glucuronidase (GUS) uidA reporter gene has also been used successfully in several algal species such as D. salina, Porphyra yezoensis, Thalassiosira weissflogii, C. fusiformis, C. kessleri, C. vulgaris, and Porphyra miniata where different $\beta$ glucuronidase substrates, like 4methylumbelliferyl- $\beta$-D-glucuronide (MUG), 5-bromo-4-chloro-3-indolyl glucuronide (XGluc) or p-nitrophenyl $\beta$-D-glucuronide help to analyze protein expression, both at subcellular localization level and spectrophotometry quantification (Tan et al., 2005; Cheney et al., 2001; Falciatore et al., 1999; El-Sheekh, 1999; Chow and Tung, 1999; Hallmann, 2007).
In Chlorella ellipsoidea and $P$. tricornutum, firefly luciferase gene was used as a reporter system (Jarvis and Brown, 1991; Falciatore et al., 1999); and the expression of luciferase is detected by in-vitro imaging. Another Escherichia coli $\beta$-galactosidase (lacZ) gene was shown to be an important reporter gene for Gracilaria changii, which requires invitro application of the substrate 5-bromo-4chloro-3-indolyl- $\beta$ - D-galactoside (X-gal) (Hallmann, 2007). In diatoms, T. weissflogii and $C$. fusiformis, the GFP gene, was used as reporter gene (Poulsen and Kröger, 2005). In $P$. tricornutum and $V$. carteri, overexpression of a gene encoding glucose transporters (glut1 or HUP1), allows these algae to grow in dark on exogenous glucose (Hallmann, 2007). These reporter genes can be used to assist in successful transformation phenomenon of algae.

\section{References}

Anila, N., Chandrashekar, A., Ravishankar, G. A., and Sarada, R. (2011). Establishment of Agrobacterium tumefaciens-mediated genetic transformation in Dunaliella bardawil. European Journal of phycology, 46(1), 36-44.

Apt, K. E., Grossman, A. R., and Kroth-Pancic, P. G. (1996). Stable nuclear transformation of the diatom Phaeodactylum tricornutum. Molecular and General Genetics MGG, 252(5), 572579.

Barbier, G., Oesterhelt, C., Larson, M. D., Halgren, R. G., Wilkerson, C., Garavito, R. M., and Weber, A. P. (2005). Comparative genomics of two closely related unicellular thermo-acidophilic red algae, Galdieria sulphuraria and Cyanidioschyzon merolae, reveals the molecular basis of the metabolic flexibility of Galdieria sulphuraria and significant differences in carbohydrate metabolism of both algae. Plant physiology, 137(2), 460-474. 
Benfey, P. N., Ren, L., and Chua, N. H. (1990). Tissue-specific expression from CaMV $35 \mathrm{~S}$ enhancer subdomains in early stages of plant development. The EMBO journal, 9(6), 1677.

Berthold, P., Schmitt, R., and Mages, W. (2002). An engineered Streptomyces hygroscopicus aph 7 "gene mediates dominant resistance against hygromycin B in Chlamydomonas reinhardtii. Protist, 153(4), 401-412.

Bhattacharya, D., Qiu, H., Price, D. C., and Yoon, H. S. (2015). Why we need more algal genomes. Journal of Phycology, 51(1), 1-5.

Blanc, G., Duncan, G., Agarkova, I., Borodovsky, M., Gurnon, J., Kuo, A., and Salamov, A. (2010). The Chlorella variabilis NC64A genome reveals adaptation to photosymbiosis, coevolution with viruses, and cryptic sex. The Plant Cell, 22(9), 2943-2955.

Cerutti, H., Johnson, A. M., Gillham, N. W., and Boynton, J. E. (1997). A eubacterial gene conferring spectinomycin resistance on Chlamydomonas reinhardtii: integration into the nuclear genome and gene expression. Genetics, 145(1), 97110.

Cheney, D., Metz, B., and Stiller, J. (2001). Agrobacterium-mediated genetic transformation in the macroscopic marine red alga Porphyra yezoensis. Journal of Phycology, 37(3), 11.

Cheng, R., Ma, R., Li, K., Rong, H., Lin, X., Wang, Z., and Ma, Y. (2012). Agrobacterium tumefaciens mediated transformation of marine microalgae Schizochytrium. Microbiological research, 167(3), 179-186.

Chow, K. C., and Tung, W. L. (1999). Electrotransformation of Chlorella vulgaris. Plant Cell Reports, 18(9), 778780.

Davies, J. P., Weeks, D. P., and Grossman, A. R. (1992). Expression of the arylsulfatase gene from the $\beta 2$-tubulin promoter in Chlamydomonas reinhardtii. Nucleic acids research, 20(12), 2959-2965.
Dawson, H. N., Burlingame, R., and Cannons, A. C. (1997). Stable transformation of Chlorella: rescue of nitrate reductasedeficient mutants with the nitrate reductase gene. Current microbiology, 35(6), 356-362.

Debuchy, R., Purton, S., and Rochaix, J. D. (1989). The argininosuccinate lyase gene of Chlamydomonas reinhardtii: an important tool for nuclear transformation and for correlating the genetic and molecular maps of the ARG7 locus. The EMBO journal, 8(10), 2803.

Derelle, E., Ferraz, C., Rombauts, S., Rouzé, P., Worden, A. Z., Robbens, S., and Saeys, Y. (2006). Genome analysis of the smallest free-living eukaryote Ostreococcus tauri unveils many unique features. Proceedings of the National Academy of Sciences, 103(31), 1164711652.

Donaher, N., Tanifuji, G., Onodera, N. T., Malfatti, S. A., Chain, P. S., Hara, Y., and Archibald, J. M. (2009). The complete plastid genome sequence of the secondarily nonphotosynthetic alga Cryptomonas paramecium: reduction, compaction, and accelerated evolutionary rate. Genome biology and evolution, 1, 439-448.

Dunahay, T. G., Jarvis, E. E., and Roessler, P. G. (1995). Genetic transformation of the diatoms Cyclotella cryptica and Navicula saprophila. Journal of Phycology, 31(6), 1004-1012.

El-Sheekh, M. M. (1999). Stable transformation of the intact cells of Chlorella kessleri with high velocity microprojectiles. Biologia Plantarum, 42(2), 209-216.

Ender, F., Godl, K., Wenzl, S., and Sumper, M. (2002). Evidence for autocatalytic crosslinking of hydroxyproline-rich glycoproteins during extracellular matrix assembly in Volvox. The Plant Cell, 14(5), 1147-1160.

Falciatore, A., Casotti, R., Leblanc, C., Abrescia, C., and Bowler, C. (1999). Transformation of nonselectable reporter genes in marine diatoms. Marine 
Biotechnology, 1(3), 239-251.

Fischer, H., Robl, I., Sumper, M., and Kröger, N. (1999). Targeting and covalent modification of cell wall and membrane proteins heterologously expressed in the diatom Cylindrotheca fusiformis (Bacillariophyceae). Journal of Phycology, 35(1), 113-120.

Fuhrmann, M., Hausherr, A., Ferbitz, L., Schödl, T., Heitzer, M., and Hegemann, P. (2004). Monitoring dynamic expression of nuclear genes in Chlamydomonas reinhardtii by using a synthetic luciferase reporter gene. Plant molecular biology, 55(6), 869-881.

Fuhrmann, M., Oertel, W., and Hegemann, P. (1999). A synthetic gene coding for the green fluorescent protein (GFP) is a versatile reporter in Chlamydomonas reinhardtii. The Plant Journal, 19(3), 353-361.

Gan, S. Y., Lim, P. E., and Phang, S. M. (2016). Genetic and Metabolic Engineering of Microalgae. In Algae Biotechnology (pp. 317-344). Springer International Publishing.

Gimpel, J. A., Hyun, J. S., Schoepp, N. G., and Mayfield, S. P. (2015). Production of recombinant proteins in microalgae at pilot greenhouse scale. Biotechnology and bioengineering, 112(2), 339-345.

GOBASE, http: //www.bch. umontreal.ca/gobase/gobase.html

Hallmann, A. (2007). Algal transgenics and biotechnology. Transgenic Plant J, 1(1), 81-98.

Hallmann, A., and Sumper, M. (1994). An inducible arylsulfatase of Volvox carteri with properties suitable for a reporter- gene system. European Journal of Biochemistry, 221(1), 143-150.

http://www.ncbi.nlm.nih.gov/genomes/ORGAN ELLES/ organelles.html

http://www.ncbi.nlm.nih.gov/projects/dbEST/

Huang, X., Weber, J. C., Hinson, T. K., Mathieson, A. C., and Minocha, S. C. (1996). Transient expression of the GUS reporter gene in the protoplasts and partially digested cells of Ulva lactuca
L.(Chlorophyta). Botanica marina, 39(16), 467-474.

Jarvis, E. E., and Brown, L. M. (1991). Transient expression of firefly luciferase in protoplasts of the green alga Chlorella ellipsoidea. Current genetics, 19(4), 317321.

Khan, H., Parks, N., Kozera, C., Curtis, B. A., Parsons, B. J., Bowman, S., and Archibald, J. M. (2007). Plastid genome sequence of the cryptophyte alga Rhodomonas salina CCMP1319: lateral transfer of putative DNA replication machinery and a test of chromist plastid phylogeny. Molecular biology and evolution, 24(8), 1832-1842.

Kilian, O., Benemann, C. S., Niyogi, K. K., and Vick, B. (2011). High-efficiency homologous recombination in the oilproducing alga Nannochloropsis sp. Proceedings of the National Academy of Sciences, 108(52), 21265-21269.

Kim, S. K. (2015) Handbook of marine microalgae. Biotechnoloy Advances.

Kindle, K. L., Schnell, R. A., Fernández, E., and Lefebvre, P. A. (1989). Stable nuclear transformation of Chlamydomonas using the Chlamydomonas gene for nitrate reductase. The Journal of cell biology, 109(6), 2589-2601.

Kovar, J. L., Zhang, J., Funke, R. P., and Weeks, D. P. (2002). Molecular analysis of the acetolactate synthase gene of Chlamydomonas reinhardtii and development of a genetically engineered gene as a dominant selectable marker for genetic transformation. The Plant Journal, 29(1), 109-117.

Li, J., Lu, Y., Xue, L., and Xie, H. (2010). A structurally novel salt-regulated promoter of duplicated carbonic anhydrase gene 1 from Dunaliella salina. Molecular biology reports, 37(2), 1143-1154.

Lommer, M., Specht, M., Roy, A. S., Kraemer, L., Andreson, R., Gutowska, M. A., and Beiko, R. G. (2012). Genome and lowiron response of an oceanic diatom adapted to chronic iron limitation. Genome biology, 13(7), 1-21. 
Lu, Y., Li, J., Xue, L., Yan, H., Yuan, H., and Wang, C. (2011). A duplicated carbonic anhydrase 1 (DCA1) promoter mediates the nitrate reductase gene switch of Dunaliella salina. Journal of Applied Phycology, 23(4), 673-680.

Matsuzaki, M., Misumi, O., Shin-i, T., Maruyama, S., Takahara, M., Miyagishima, S. Y., and Yoshida, Y. (2004). Genome sequence of the ultrasmall unicellular red alga Cyanidioschyzon merolae 10D. Nature, 428(6983), 653-657.

Maul, J. E., Lilly, J. W., Cui, L., Miller, W., Harris, E. H., and Stern, D. B. (2002). The Chlamydomonas reinhardtii plastid chromosome islands of genes in a sea of repeats, The Plant Cell, 14(11), 26592679.

Melton III, J. T., Leliaert, F., Tronholm, A., and Lopez-Bautista, J. M. (2015). The complete chloroplast and mitochondrial genomes of the green macroalga Ulva sp. UNA00071828 (Ulvophyceae, Chlorophyta). PLoS One, 10(4), e0121020.

Merchant, S. S., Prochnik, S. E., Vallon, O., Harris, E. H., Karpowicz, S. J., Witman, G. B., and Marshall, W. F. (2007). The Chlamydomonas genome reveals the evolution of key animal and plant functions. Science, 318(5848), 245-250.

Minoda, A., Sakagami, R., Yagisawa, F., Kuroiwa, T., and Tanaka, K. (2004). Improvement of culture conditions and evidence for nuclear transformation by homologous recombination in a red alga, Cyanidioschyzon merolae 10D. Plant and Cell Physiology, 45(6), 667-671.

Miyagawa- Yamaguchi, A., Okami, T., Kira, N., Yamaguchi, H., Ohnishi, K., and Adachi, M. (2011). Stable nuclear transformation of the diatom Chaetoceros sp. Phycological research, 59(2), 113119.

Muravenko, O., Selyakh, I., Kononenko, N., and Stadnichuk, I. (2001). Chromosome numbers and nuclear DNA contents in the red microalgae Cyanidium caldarium and three Galdieria species. European Journal of Phycology, 36(3), 227-232.

Nelson, J. A., Savereide, P. B., and Lefebvre, P. A. (1994). The CRY1 gene in Chlamydomonas reinhardtii: structure and use as a dominant selectable marker for nuclear transformation. Molecular and cellular biology, 14(6), 4011-4019.

OGMP, http: //www.bch. umontreal.ca/ogmp/

Ota, S., Oshima, K., Yamazaki, T., Kim, S., Yu, Z., Yoshihara, M., and Zachleder, V. (2016). Highly efficient lipid production in the green alga Parachlorella kessleri: draft genome and transcriptome endorsed by whole-cell 3D ultrastructure. Biotechnology for biofuels, 9(1), 1-10.

Oudot-Le Secq, M. P., Grimwood, J., Shapiro, H., Armbrust, E. V., Bowler, C., and Green, B. R. (2007). Chloroplast genomes of the diatoms Phaeodactylum tricornutum and Thalassiosira pseudonana: comparison with other plastid genomes of the red lineage. Molecular Genetics and Genomics, 277(4), 427-439.

Palenik, B., Grimwood, J., Aerts, A., Rouzé, P., Salamov, A., Putnam, N., and Zhou, K. (2007). The tiny eukaryote Ostreococcus provides genomic insights into the paradox of plankton speciation. Proceedings of the National Academy of Sciences, 104(18), 7705-7710.

Pan, K., Qin, J., Li, S., Dai, W., Zhu, B., Jin, Y., and Li, D. (2011). Nuclear monoploidy and asexual propagation of Nannochloropsis oceanica (eustigmatophyceae) as revealed by its genome sequence1. Journal of phycology, 47(6), 1425-1432.

Poulsen, N., and Kröger, N. (2005). A new molecular tool for transgenic diatoms. Febs Journal, 272(13), 3413-3423.

Prochnik, S. E., Umen, J., Nedelcu, A. M., Hallmann, A., Miller, S. M., Nishii, I., and Hellsten, U. (2010). Genomic analysis of organismal complexity in the multicellular green alga Volvox carteri. Science, 329(5988), 223-226.

Puerta, M. V. S., Bachvaroff, T. R., and 
Delwiche, C. F. (2005). The complete plastid genome sequence of the haptophyte Emiliania huxleyi: a comparison to other plastid genomes. DNA Research, 12(2), 151-156.

Qin, S., Sun, G. Q., Jiang, P., Zou, L. H., Wu, Y., and Tseng, C. K. (1999). Review of genetic engineering of Laminaria japonica (Laminariales, Phaeophyta) in China. In Sixteenth International Seaweed Symposium (pp. 469-472). Springer Netherlands.

Randolph-Anderson, B. L., Sato, R., Johnson, A. M., Harris, E. H., Hauser, C. R., Oeda, K., and Boynton, J. E. (1998). Isolation and characterization of a mutant protoporphyrinogen oxidase gene from Chlamydomonas reinhardtii conferring resistance to porphyric herbicides. Plant molecular biology, 38(5), 839-859.

Rathod, J. P., Prakash, G., Pandit, R., and Lali, A. M. (2013). Agrobacterium-mediated transformation of promising oil-bearing marine algae Parachlorella kessleri. Photosynthesis research, 118(1-2), 141146.

Rathod, J. P., Prakash, G., Vira, C., and Lali, A. M. (2016). Trehalose phosphate synthase overexpression in Parachlorella kessleri improves growth and photosynthetic performance under high light conditions. Preparative Biochemistry and Biotechnology, 46(8), 803-809.

Read, B. A., Kegel, J., Klute, M. J., Kuo, A., Lefebvre, S. C., Maumus, F., and Young, J. (2013). Pan genome of the phytoplankton Emiliania underpins its global distribution. Nature, 499(7457), 209-213.

Schiedlmeier, B., Schmitt, R. C. D. I. G. E. R., Müller, W., Kirk, M. M., Gruber, H., Mages, W., and Kirk, D. L. (1994). Nuclear transformation of Volvox carteri. Proceedings of the National Academy of Sciences, 91(11), 5080-5084.

Schroda, M., Blöcker, D., and Beck, C. F. (2000). The HSP70A promoter as a tool for the improved expression of transgenes in Chlamydomonas. The plant journal,
21(2), 121-131.

Sizova, I., Fuhrmann, M., and Hegemann, P. (2001). A Streptomyces rimosusaphVIII gene coding for a new type phosphotransferase provides stable antibiotic resistance to Chlamydomonas reinhardtii. Gene, 277(1), 221-229.

Smith, D. R., Lee, R. W., Cushman, J. C., Magnuson, J. K., Tran, D., and Polle, J. E. (2010). The Dunaliella salina organelle genomes: large sequences, inflated with intronic and intergenic DNA. BMC plant biology, 10(1), 83.

Steinbrenner, J., and Sandmann, G. (2006). Transformation of the green alga Haematococcus pluvialis with a phytoene desaturase for accelerated astaxanthin biosynthesis. Applied and environmental microbiology, 72(12), 7477-7484.

Stevens, D. R., Purton, S., and Rochaix, J. D. (1996). The bacterial phleomycin resistance geneble as a dominant selectable marker in Chlamydomonas. Molecular and General Genetics MGG, 251(1), 23-30.

Sun, Y., Gao, X., Li, Q., Zhang, Q., and Xu, Z. (2006). Functional complementation of a nitrate reductase defective mutant of a green alga Dunaliella viridis by introducing the nitrate reductase gene. Gene, 377, 140-149.

Takahashi, M., Uji, T., Saga, N., and Mikami, K. (2010). Isolation and regeneration of transiently transformed protoplasts from gametophytic blades of the marine red alga Porphyra yezoensis. Electronic Journal of Biotechnology, 13(2), 8-9.

Tan, C., Qin, S., Zhang, Q., Jiang, P., and Zhao, F. (2005). Establishment of a microparticle bombardment transformation system for Dunaliella salina. Journal of Microbiology-Seoul-, 43(4), 361.

TBestDB,

http://amoebidia.bcm.umontreal.ca/pepdb / searches/welcome.php

Te, M. R., and Miller, D. J. (1998). Genetic transformation of dinoflagellates (Amphidinium and Symbiodinium): expression of $G U S$ in microalgae using 
heterologous promoter constructs. The Plant Journal, 13(3), 427-435.

Turmel, M., Otis, C., and Lemieux, C. (2009). The chloroplast genomes of the green algae Pedinomonas minor, Parachlorella kessleri, and Oocystis solitaria reveal a shared ancestry between the Pedinomonadales and Chlorellales. Molecular biology and evolution, 26(10), 2317-2331.

Vira, C., Prakash, G., Rathod, J. P., and Lali, A. M. (2016). Cloning, expression, and purification of Chlamydomonas reinhardtii CC-503 sedoheptulose 1, 7bisphosphatase in Escherichia coli. Preparative Biochemistry and Biotechnology, 46(8), 810-814.

Wakasugi, T., Nagai, T., Kapoor, M., Sugita, M., Ito, M., Ito, S., and Hamada, A. (1997). Complete nucleotide sequence of the chloroplast genome from the green alga Chlorella vulgaris: the existence of genes possibly involved in chloroplast division. Proceedings of the National Academy of Sciences, 94(11), 5967-5972.
Wang, B., Wang, J., Zhang, W., and Meldrum, D. R. (2012). Application of synthetic biology in cyanobacteria and algae. Front Microbiol, 3(344), 344.

Wang, J., Jiang, P., Cui, Y., Guan, X., and Qin, S. (2010). Gene transfer into conchospores of Porphyra haitanensis (Bangiales, Rhodophyta) by glass bead agitation. Phycologia, 49(4), 355-360.

Worden, A. Z., Lee, J. H., Mock, T., Rouzé, P., Simmons, M. P., Aerts, A. L., and Foulon, E. (2009). Green evolution and dynamic adaptations revealed by genomes of the marine picoeukaryotes Micromonas. Science, 324(5924), 268 272.

Zaslavskaia, L. A., Lippmeier, J. C., Kroth, P. G., Grossman, A. R., and Apt, K. E. (2000). Transformation of the diatom Phaeodactylum tricornutum (Bacillariophyceae) with a variety of selectable marker and reporter genes. Journal of Phycology, 36(2), 379-386.

\section{How to cite this article:}

Jayant Pralhad Rathod, Rajendra M. Gade, Darasing R. Rathod and Mahendra Dudhare. 2017. A Review on Genetic Engineering of Microalgae with Respect to Genomes, Selectable Marker Genes, Promoters and Reporter Genes. Int.J.Curr.Microbiol.App.Sci. 6(12): 3208-3219. doi: https://doi.org/10.20546/ijcmas.2017.612.374 